\title{
PEMBELAJARAN PROBLEM BASED LEARNING DALAM IMPLEMENTASI KURIKULUM 2013 DI SMK
}

\author{
Herminarto Sofyan \\ Fakultas Teknik Universitas Negeri Yogyakarta \\ hermin@uny.ac.id \\ Kokom Komariah \\ Fakultas Teknik Universitas Negeri Yogyakarta \\ kokom@uny.ac.id
}

\begin{abstract}
Penelitian ini bertujuan untuk menggambarkan kondisi awal pembelajaran dalam penerapan Kurikulum 2013 SMK dan kondisi pembelajaran setelah diterapkan Problem Based Learning $(P B L)$. Penelitian ini merupakan bagian dari pengembangan model pembelajaran PBL dalam Penerapan Kurikulum 2013. Populasi dalam penelitian ini adalah guru-guru yang mencoba menerapakan PBL dalam penerapan Kurikulum 2013. Data dikumpulkan dengan teknik angket dan wawancara melalui Focused Group Discussion (FGD). Analisis data dilakukan secara deskriptif. Hasil penelitian tahun pertama menunjukkkan bahwa: (a) PBL sangat potensial diterapkan dalam penerapan Kurikulum 2013 di SMK. Kesiapan guru dalam implementasi Kurikulum 2013 termasuk dalam kategori tinggi dengan harga rerata sebesar 96,73 dan pencapaian skor 71,9\%. Kesesuaian implementasi pembelajaran dalam penerapan Kurikulum 2013 termasuk kategori tinggi dengan rerata 152,26 dan pencapaian skor 78,40\%. Sebagian besar guru menyatakan bahwa PBL layak diterapkan di setiap mata pelajaran dalam implementasi Kurikulum 2013; (b) PBL terbukti mampu meningkatkan kompetensi siswa dalam aspek kemampuan (hard skills) maupun sikap (soft skills).
\end{abstract}

Kata kunci: Kurikulum 2013, SMK, Probem Based Learning

\section{PROBLEM BASED LEARNING IN THE 2013 CURICULLUM IMPLEMENTATION OF VOCATIONAL HIGH SCHOOL}

\begin{abstract}
This study aims to describe the pre-learning condition in 2013 curriculum implementation of vocational high school (VHS) and the post-learning condition that Problem Based Learning (PBL) has been implemented. The research is a part of PBL learning model development in 2013 curriculum implementation. The population of this study is the teachers who try to apply PBL in 2013 curriculum implementation. Data collection was done by questionnaire and interview through the Focused Group Discussion (FGD). Data analysis was conducted descriptively. The first year research finding shows: (a) PBL is very potential to be implemented in 2013 curriculum implementation of vocational high school. Teachers' readiness in 2013 curriculum implementation came into the high category with average score $97.63 \%$ and the attainment score $71.9 \%$. The compatibility of learning implementation in 2013 curriculum came into the high category with average score 152.26 and the attainment score $78.40 \%$. The majority of teachers explained that $P B L$ is valid to be implemented in every subject matter in the 2013 curriculum implementation; (b) $P B L$ is evident can increase the students competence in the hard skills and soft skills aspect.
\end{abstract}

Keywords: 2013 Curriculum, VHS, Problem Based Learning 


\section{PENDAHULUAN}

Pendidikan kejuruan, dalam hal ini Sekolah Menengah Kejuruan (SMK) yang mempersiapkan peserta didik terutama untuk bekerja dalam bidang tertentu (Undang-Undang Nomor 20 Tahun 2003) memiliki peran strategis dalam menyiapkan SDM khususnya tenaga kerja tingkat menengah. Pengalaman di lapangam meupun data proyeksi perencanaan pembangunan menunjukkan bahwa ditinjau dari prospek kebutuhan maupun kelayakkan ekonomisnya pendidikan kejuruan masih merupakan investasi yang cukup baik dalam mempersiapkan tenaga terampil tingkat menengah (Sukamto, 2001, p. 10). Hal senada dikatakan oleh Wardiman (2016, p. 313) bahwa SMK adalah sekolah kejuruan untuk mencetak lulusan yang terampil dan langsung bisa masuk ke dunia kerja.

Paradigma pengembangan pendidikan kejuruan ke depan tentu tidak terlepas dari karakteristik dunia kerja dan tenaga kerja yang dibutuhkan dalam era mendatang. Dalam kacamata pendidikan kejuruan, pertanyaan mendasar yang perlu dijawab adalah seberapa relevan learning outcome yang dihasilkan dunia pendidikan dengan karakteristik tenaga kerja yang dibutuhkan di masa mendatang. Berbagai kajian merumuskan learning outcome yang diperlukan bagi lulusan dalam menghadapi tantangan ketenagakerjaan ke depan. The Partnership for 21 st Century Skills (www.21centuryskills.org.) merumuskan $21 s t$ century student outcomes and support system yang tampak pada Gambar 1.
Pemikiran yang tertuang pada Gambar 1 tersebut menunjukkan cara pandang holistik tentang pembelajaran yang diperlukan guna mewujudkan lulusan yang memiliki kompetensi komprehensif. Kompetensi tersebut meliputi aspek kemampuan dasar (bahasa, seni, matematik, ekonomi, sain, geografi, sejarah, dan kewarganegaraan); kemampuan belajar dan inovasi (kreativitas dan inovasi, berpikir kritis, komunikasi, dan kolaborasi); kemampuan mengelola informasi, media, dan teknologi informasi; serta kemampuan hidup dan karir (life and career skills). Apabila dilihat dari dimensi-dimensi yang tertuang dalam kompetensi yang diharapkan tersebut, tampak jelas bahwa penanaman karakter merupakan tuntutan bagi lulusan agar mampu berjaya di era mendatang.

Penerapan Kurikulum 2013 merupakan salah satu upaya pemerintah untuk lebih meningkatkan kualitas lulusan sesuai dengan tujuan pendidikan. Perubahan Kurikulum 2013 diharapkan dapat menghasilkan insan Indonesia yang produktif, kreatif, inovatif, dan afektif melalui penguatan sikap (tahu mengapa), keterampilan (tahu bagaimana), dan pengetahuan (tahu apa) yang terintegrasi. Hal ini dalam rangka menyongsong perkembangan kehidupan dan ilmu pengetahuan abad 21 , yang mengalami pergeseran baik ciri maupun model pembelajaran. Skema pada Gambar 2 berikut ini menunjukkan pergeseran paradigma belajar abad 21 yang berdasarkan ciri abad 21 dan model pembelajaran yang harus dilakukan (www.kemdikbud.go.id).

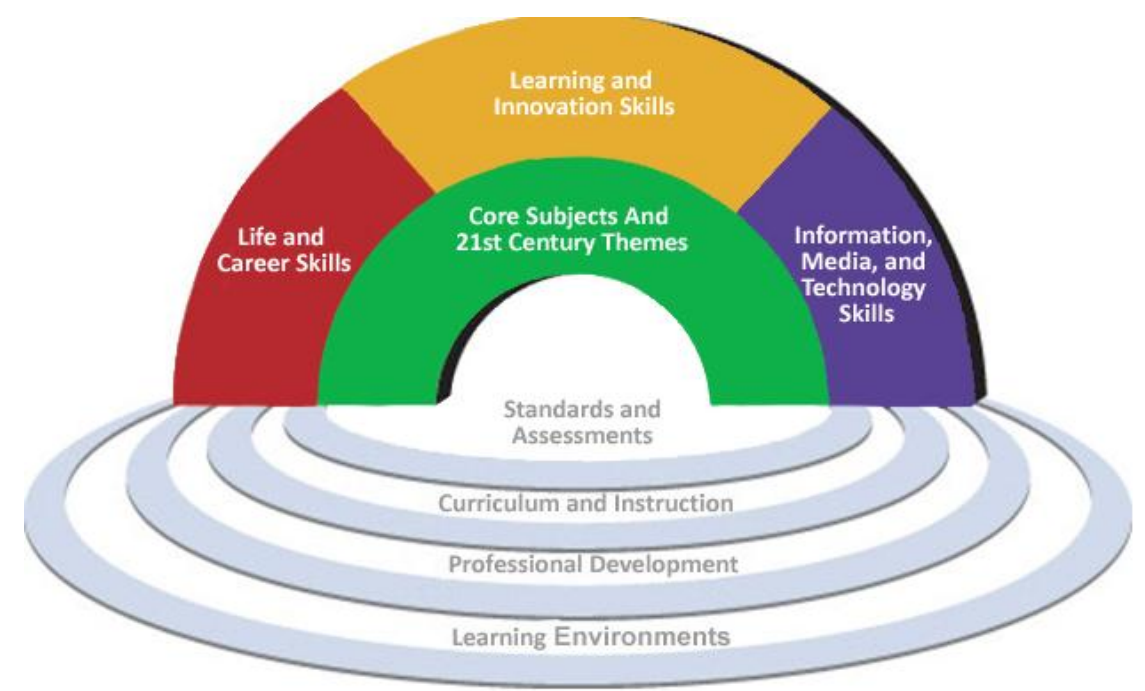

Gambar 1. 21st Century Student Outcomes and Support System 
Skema 1. Pergeseran Paradigma Belajar Abad 21

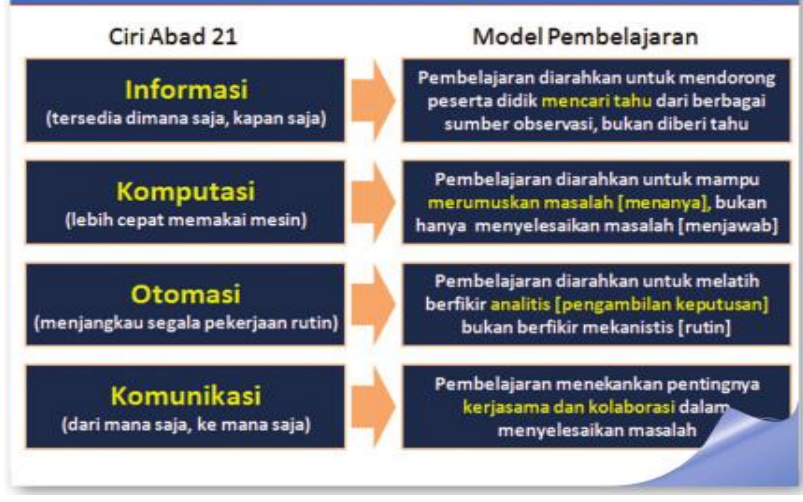

Gambar 1. Posisi Kurikulum 2013

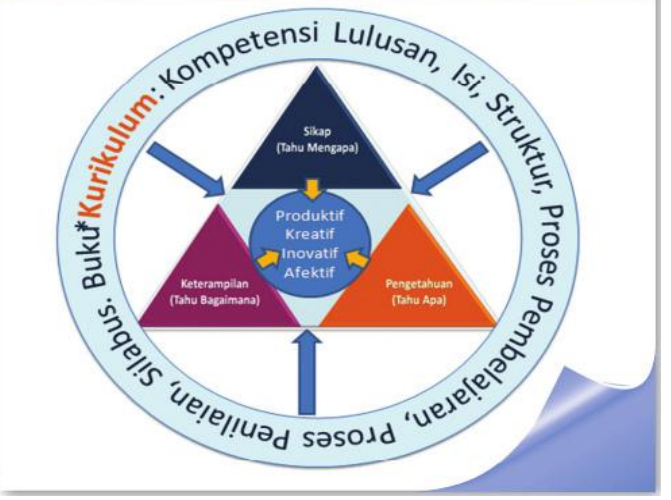

Gambar 2. Paradigma Pengembangan Kurikulum 2013

Gambar 2 menunjukkan posisi Kurikulum 2013 yang terintegrasi sebagaimana tema pada pengembangan Kurikulum 2013. Untuk mencapai tema itu, dibutuhkan proses pembelajaran yang mendukung kreativitas. Oleh karena itu, perlu dirumuskan kurikulum yang mengedepankan pengalaman personal melalui proses mengamati, menanya, menalar, dan mencoba (observation based learning) untuk meningkatkan kreativitas peserta didik. Di samping itu, perlu dibiasakan bagi peserta didik untuk bekerja dalam jejaringan melalui collaborative learning. Untuk menghasilkan peserta didik yang mempunyai kemampuan yang sebagaimana diharapkan dari perubahan Kurikulum 2013 ini, maka terdapat beberapa elemen perubahan sebagaimana ditunjukkan pada elemen perubahan gambar di atas (http://edukasi.kompas.com/read/2013/03/05/ $\underline{11584463)}$

Perubahan Kurikulum 2013 atau pengembangan Kurikulum 2013, diharapkan mampu mendorong peserta didik aktif dan kreatif melakukan observasi, bertanya, bernalar, dan mengomunikasikan (mempresentasikan) apa yang diperoleh atau diketahui setelah siswa menerima materi pembelajaran. Melalui pengembangan Kurikulum 2013, diharapkan peserta didik memiliki kompetensi sikap, keterampilan, dan pengetahuan yang jauh lebih baik. Peserta didik akan lebih kreatif, inovatif, dan lebih produktif. Sedikitnya ada lima entitas yaitu setiap peserta didik, pendidik dan tenaga kependidikan, manajemen satuan pendidikan, negara dan bangsa, serta masyarakat umum, yang diharapkan mengalami perubahan. Skema 2 menggambarkan perubahan yang diharapkan pada setiap entitas (http://kemdikbud.go.id/kemdikbud/artikelmenyongsong-penerapan-kurikulum2013).

Perubahan kurikulum menuntut perubahan paradigma pembelajaran dari teaching ke learnin, dari teaching community ke learning community. Dengan demikian, guru dituntut untuk kreatif dan inovatif dalam mendesain pembelajaran agar peserta didik termotivasi dan merasa senang selama pembelajaran berlangsung. Oleh karena itu, harus ada upaya-upaya dari guru tentang bagaimana mengembangkan pembelajaran agar pembelajaran menjadi menarik, menyenangkan, memotivasi siswa untuk belajar mandiri.

Dalam tataran operasional, sasaran pembelajaran mencakup pengembangan ranah sikap, pengetahuan, dan keterampilan yang dielaborasi untuk setiap satuan pendidikan. Ketiga ranah kompetensi tersebut memiliki lintasan perolehan (proses psikologis) yang berbeda. Sikap diperoleh melalui aktivitas "menerima, menjalankan, menghargai, menghayati, dan mengamalkan". Pengetahuan diperoleh melalui aktivitas "mengingat, memahami, menerapkan, menganalisis, mengevaluasi, mencipta". Keterampilan diperoleh melalui aktivitas "mengamati, menanya, mencoba, menalar, menyaji, dan mencipta". Karaktersitik kompetensi beserta perbedaan lintasan perolehan turut serta mempengaruhi karakteristik standar proses (Permendikbud Nomor 65 Tahun 2013). Untuk memperkuat pendekatan ilmiah (scientific), tematik terpadu (tematik antarmata pelajaran), dan tematik (dalam suatu mata pelajaran) perlu diterapkan pembelajaran berbasis penyingkapan/penelitian (discovery/inquiry learning). Untuk mendorong kemampuan peserta didik menghasil- 
kan karya kontekstual, baik individual ataupun kelompok maka sangat disarankan menggunakan pendekatan pembelajaran yang menghasilkan karya berbasis pemecahan masalah (project based learning). Pendekatan/model belajar yang diharapkan dalam penerapan Kurikulum 2013 meliputi karakteristik tematik terpadu, pendekatan scientific, discovery learning, problem based learning, dan project based learning.

Problem Based Learning (PBL) merupakan salah satu metode pembelajaran yang layak dikembangkan seiring dengan tuntutan pembelajaran dalam penerapan Kurikulum 2013. Hal ini selaras dengan karakteristik PBL sebagai suatu metode pembelajaran konstruktivistik berorientasi student centered learning yang mampu menumbuhkan jiwa kreatif, kolaboratif, berpikir metakognisi, mengembangkan kemampuan berpikir tingkat tinggi, meningkatkan pemahaman akan makna, meningkatkan kemandirian, memfasilitasi pemecahan masalah, dan membangun teamwork. Dengan demikian upaya perumusan model pembelajaran tersebut mendesak dilakukan dalam upaya meningkatkan efektivitas implementasi Kurikulum 2013. Namun demikian, hingga saat ini belum ditemukan model dan formula yang tepat dalam implementasi PBL tersebut sebagai rujukan pembelajaran terutama di SMK. Oleh karenanya diperlukan kajian kondisi awal pembelajaran dalam penerapan Kurikulum 2013, dan kondisi setelah diterapkannya PBL. Hasil peneltian ini diharapkan menjadi rujukan bagi SMK di Indonesia dalam mengimplementasikan pembelajaran khusunya PBL selaras dengan tuntutan pembelajaran dalam Implementasi Kurikulum 2013.

\section{Problem-Based Learning}

Pembelajaran berbasis masalah (Problem-based Learning) merupakan salah satu model yang tepat dikembangkan dalam pembelajaran teknologi untuk merespon isu-isu peningkatan kualitas pembelajaran teknologi dan antisipasi perubahan-perubahan yang terjadi di dunia kerja. Pembelajaran Berbasis Masalah (PBL) adalah strategi pembelajaran yang "menggerakkan" siswa belajar secara aktif memecahkan masalah yang kompleks dalam situasi realistik. PBL dapat digunakan untuk pembelajaran di tingkat mata pelajaran, unit matapelajaran, atau keseluruhan kuri- kulum. PBL seringkali dilakukan dalam lingkungan belajar tim dengan penekanan pada kegiatan membangun pengetahuan dan keterampilan yang berhubungan dengan pengambilan keputusan secara konsensus, dialog dan diskusi, kerja sama tim, manajemen konflik, dan kepemimpinan tim.

PBL merupakan pendekatan yang berorientasi pada pandangan konstruktivistik yang memuat karakteristik kontekstual, kolaboratif, berpikir metakognisi, dan memfasilitasi pemecahan masalah. Siswa dimungkinkan belajar secara bermakna yang dapat mengembangkan kemampuan berpikir tingkat tinggi melalui pemecahan masalah. PBL merupakan pendekatan yang membelajarkan siswa yang dikonfrontasikan dengan masalah praktis, berbentuk ill-structured, atau open ended melalui stimulan dalam belajar (Boud dan Falleti, 1997 dalam Demitra, 2003).

Pembelajaran berbasis masalah (Problem-based Learning) juga merupakan pendekatan pembelajaran yang menggunakan masalah dunia nyata sebagai suatu konteks bagi siswa untuk belajar tentang cara berpikir kritis dan keterampilan pemecahan masalah, serta untuk memperoleh pengetahuan dan konsep yang esensial dari materi pelajaran. (Nurhadi, 2004). Dengan demikian PBL merupakan pembelajaran yang dipandu oleh permasalahan dimana sebelumnya siswa diberikan permasalahan. Dalam hal ini diperlukan pengetahuan baru untuk memecahkannnya (http://chemeng.mcmaster.ca/pbl/pbl.htm). Hal ini sejalan dengan yang Tan (2004, p. 7) menyatakan:

Problem-based learning is recognized as a progressive active-learning and learner-centered approach where unstructured problems (real-world or simulated complex problems) are used as the starting point and anchor for the learning process.

Pembelajaran berbasis masalah juga merupakan pembelajaran yang berpusat pada peserta didik, serta didasari pada permasalahan nyata/real world problem (http://www.pbli. org/pbl/pbl.htm). Lebih lanjut beberapa karakteristik pembelajaran PBL antara lain: (1) siswa harus peka terhadap lingkungan belajarnya, (2) simulasi problem yang digunakan hendaknya berbentuk ill-structured, dan memancing penemuan bebas (free for inquiry), 
(3) pembelajaran diintegrasikan dalam berbagai subjek, (4) pentingnya kolaborasi, (4) pembelajaran hendaknya menumbuhkan kemandirian siswa dalam memecahkan masalah, (5) aktivitas pemecahan masalah hendaknya mewakili pada situasi nyata, (6) penilaian hendaknya mengungkap kemajuan siswa dalam mencapai tujuan dalam pemecahan masalah, (7) PBL hendaknya merupakan dasar dari kurikulum bukan hanya pembelajaran.

Beberapa kelebihan dari metode PBL antara lain: meningkatkan pemahaman akan makna, meningkatkan kemandirian, meningkatkan pengembangan skill berpikir tingkat tinggi, meningkatkan motivasi, memfasilitasi relasi antar siswa dan meningkatkan skill dalam membangun teamwork (http://edweb. sdsu.edu/clrit/learningtree/PBL/PBLadvantag es.htm).

Pembelajaran berbasis masalah dikenal dengan nama lain seperti pembelajaran proyek (project-based learning), pendidikan berbasis pengalaman (experience based learning), pembelajaran otentik (authentic learning) dan pembelajaran berakar pada kehidupan nyata (anchored instruction). Peran guru dalam pembelajarn berbasis masalah adalah menyajikan masalah, mengajukan pertanyaan, dan memfasilitasi penyelidikan dan dialog. Pengajaran berbasis masalah tidak dapat dilaksanakan jika guru tidak mengembangkan lingkungan kelas yang memungkinkan terjadinya pertukaran ide secara terbuka. Intinya, siswa dihadapkan situasi masalah yang otentik dan bermakna yang menantang siswa untuk memecahkannya.

PBL didasarkan pada kerangka kerja teoretik konstruktivisme, social learning, situated cognition, dan komunitas praktik sebagai teori belajar. Teori-teori ini memiliki tematema umum tentang konteks dan proses belajar yang saling terkait. Landasan-landasan berpikir yang memberikan rasional PBL antara lain: Pertama, belajar bermakna sering terjadi dalam konteks tertentu. Dengan kata lain, belajar adalah makin bermakna dan dapat diperluas ketika siswa berhadapan dengan situasi di mana konsep diterapkan. Misalnya, siswa ingin mempelajari tentang anatomi dan siklus kehidupan ikan karena mereka merasa bahwa informasi ini berguna dalam penentuan sebab kematian ikan di sungai. Cara belajar ini jelas kontradiktif dengan model kurikulum tradisional. Belajar dalam kelas biologi tra- disional, siswa belajar anatomi dan siklus kehidupan ikan sebelum mereka memahami bagaimana informasi itu mungkin digunakan. Dalam situasi PBL, siswa dihadapkan pada kegiatan aplikatif dan melakukan analisis, barangkali sebelum mereka mengetahui atau memahami konsep yang tercakup dalam situasi itu. Lebih daripada itu, dalam PBL semua pengetahuan dan keterampilan secara langsung relevan dengan konteks, sedangkan dalam model kurikulum tradisional pengetahuan dan keterampilan dasar mungkin tidak pernah diaplikasikan. Para pendidik yang menerapkan PBL meyakini bahwa siswa acapkali gagal membuat hubungan antara "pengetahuan buku" dan aplikasi tanpa mereka belajar dengan aplikasi praktik. Jadi, perspektif belajar berbasis masalah menegaskan bahwa partisipasi adalah elemen penting dalam belajar.

PBL juga berdasarkan pada pandangan bahwa belajar terjadi melalui interaksi sosial sedangkan sumber-sumber belajar dapat membantu setiap individu memperluas belajar mereka. Kerangka pikirnya menegaskan bahwa pemahaman dari suatu ide atau konsep terbatas pada beberapa poin, dan menegaskan apa yang disebut dengan zone of proximal development. Zona ini dapat terjadi sepanjang tingkat pemahaman antar individu, tergantung pada keluasan pengetahuan dan pemahaman mereka. Agar dapat memperluas pemahaman yang sebelumnya mengalami hambatan, individu harus berinteraksi dengan orang atau medium yang dapat memberikan informasi baru, sehingga mendapatkan perspektif baru. Tipe interaksi eksternal ini dapat membantu siswa melampaui zone of proximal development, memperluas pemahaman mereka mengembangkan pikiran-pikiran baru yang muncul kemudian. Dalam situasi kompleks yang dikaitkan dengan PBL, siklus belajar yang majemuk saling berkoeksistensi dan berkembang secara simultan, masing menekankan pada konsep dan strategi yang berbeda.

\section{Karakteristik dan Tahapan Pembelajaran Model Problem-Based Learning}

Pembelajaran berbasis masalah dikembangkan terutama untuk membantu siswa mengembangkan kemampuan berpikir, pemecahan masalah, dan ketrampilan intelektual, belajar tentang berbagai peran orang dewasa dengan melibatkan diri dalam pengalaman nyata atau simulasi, dan menjadi pembelajar 
yang otonom dan mandiri. Pembelajaran Berbasis Masalah memerlukan beberapa tahapan dan beberapa durasi tidak sekedar merupakan rangkaian pertemuan kelas serta belajar dalam tim kolaboratif. Secara umum siswa melakukan kegiatan: mengorganisasi kegiatan belajar kelompok mereka, melakukan pengkajian atau penelitian, memecahkan masalah, dan mensintesis informasi. Pemecahan masalah selain dilakukan secara kolaboratif juga harus bersifat inovatif, unik, dan berfokus pada pemecahan masalah yang berhubungan dengan kehidupan siswa atau kebutuhan masyarakat atau industri lokal. Dari perspektif ini, jelas sekali Pembelajaran Berbasis Masalah merupakan model yang inovatif yang menekankan belajar kontekstual melalui kegiatan-kegiatan yang kompleks (CORD, 2001, p. 65). Fokus pembelajaran terletak pada konsep-konsep dan prinsip-prinsip inti dari suatu disiplin studi, melibatkan siswa dalam investigasi pemecahan masalah dan kegiatan tugas-tugas bermakna yang lain, memberi kesempatan siswa bekerja secara otonom mengkonstruk pengetahuan mereka sendiri, dan mencapai puncaknya menghasilkan produk nyata (Thomas, 2000) http://www.autodesk.com/ foundation).

Pengajaran berbasis masalah biasanya terdiri dari lima tahap utama yang dimulai dengan suatu situasi masalah dan diakhiri dengan penyajian dan analisis hasil kerja siswa. Dalam penyusunannya maka problem yang digunakan berciri; menunjukkan lingkungan atau situasi yang mewakili situasi nyata, masalah benar-benar nyata, masalah memungkinkan untuk dipecahkan, interdisiplin, objektif, berorientasi pada penyelesaian tugas, serta membutuhkan pengetahuan yang kompleks. Dalam strukturnya akan terdiri dari pengantar, isi, dasar teori, bahan, hasil yang diharapkan. Disamping itu pembelajaran model PBL juga bercirikan penyelesaian masalah dalam kelompok-kelompok kecil yang mandiri (http://edweb.sdsu.edu/clrit/learningtreel PBL/PBLadvantages.html). Secara rinci tahapan-tahapan pembelajaran model PBL dapat dilihat pada Tabel 1.

Secara operasional pembelajaran masalah dapat dilakukan melalui langkah-langkah sebagai berikut: (1) problem diberikan di dalam urutan belajar, sebelum persiapan atau berlangsungnya kegiatan, (2) situasi masalah diberikan kepada siswa dalam cara yang sama seperti masalah itu terjadi di dunia nyata, (3) siswa bekerja menyelesaikan masalah yang dapat memberi peluang dirinya berpikir dan menggunakan pengetahuannya, sesuai dengan level belajarnya, (4) lingkup belajar pemecahan masalah ditetapkan dan digunakan sebagai pemandu belajar individual, (5) pengetahuan dan keterampilan yang diperlukan untuk belajar ini, diterapkan kembali pada masalah, untuk mengevaluasi keefektifan belajar dan memberi penghargaan belajar, dan (6) belajar yang terjadi di dalam kerja dengan masalah dan dalam belajar individual, diringkas dan diintegrasikan ke dalam pengetahuan dan keterampilan siswa yang sudah dimiliki (Muslimin \& Moh. Nur, 2000, p. 13).

Tabel 1. Tahapan-Tahapan Pembelajaran PBL

\begin{tabular}{ll}
\hline Tahapan & Tingkah Laku Guru \\
\hline $\begin{array}{l}\text { Tahap 1 Orientasi siswa } \\
\text { kepada masalah }\end{array}$ & $\begin{array}{l}\text { Guru menjelaskan tujuan pembelajaran, menjelaskan logistik yang } \\
\text { dibutuhkan, memotivasi siswa agar terlibat pada aktivitas } \\
\text { pemecahan masalah yang dipilihnya }\end{array}$ \\
$\begin{array}{l}\text { Tahap 2. Mengorganisasi siswa } \\
\text { untuk belajar }\end{array}$ & $\begin{array}{l}\text { Guru membantu siswa mendefinisikan dan mengorganisasikan tugas } \\
\text { belajar yang berhubungan dengan masalah tersebut }\end{array}$ \\
$\begin{array}{l}\text { Tahap 3. Membimbing } \\
\text { penyelidikan individual dan } \\
\text { kelompok }\end{array}$ & $\begin{array}{l}\text { Guru mendorong siswa untuk mengumpulkan informasi yang } \\
\text { sesuai, melaksankan eksperimen, untuk mendapatkan penjelasan } \\
\text { dan pemecahan masalah }\end{array}$ \\
$\begin{array}{l}\text { Tahap 4. Mengembangkan dan } \\
\text { menyajikan hasil karya }\end{array}$ & $\begin{array}{l}\text { Guru membantu siswa merencanakan dan menyiapkan karya yang } \\
\text { sesuai seperti laporan, video, dan model serta membantu mereka } \\
\text { berbagi tugas dengan temannya }\end{array}$ \\
$\begin{array}{l}\text { Tahap 5. Menganalisis dan } \\
\text { mengevaluasi proses } \\
\text { pemecahan masalah }\end{array}$ & $\begin{array}{l}\text { Guru membantu melakukan refleksi atau evaluasi terhadap } \\
\text { penyelidikan dan proses-proses yang mereka gunakan. }\end{array}$ \\
\hline
\end{tabular}


Dari uraian tersebut terlihat bahwa pembelajaran berbasis masalah melibatkan siswa secara aktif. Siswa tidak menerima materi pelajaran semata-mata dari guru, melainkan berusaha menggali dan mengembangkan sendiri. Dengan demikian diharapkan siswa lebih termotivasi dalam belajar dan mengetahui kebermaknaan dari apa yang dipelajarinya. Hasil belajar yang diperoleh tidak semata berupa peningkatan pengetahuan, tetapi juga meningkatkan keterampilan berfikir.

\section{METODE PENELITIAN}

Penelitian ini merupakan penelitian kuantitatif dengan metode ex-post facto. Penelitian dilakukan di lima SMK di Yogyakarta dengan paket keahlian teknik pemesinan, teknik pengelasan, teknik kendaraan ringan, teknik sepeda motor, dan boga. Pupolasi penelitian adalah guru mata pelajaran produktif dari lima SMK yang terbagi dalam sembilan grup. Sampel diambil sama dengan populasi. Data dambil dengan angket dan wawancana melalui Focused Group Discussion (FGD). Data dianalisis secara deskriptif.

\section{HASIL PENELITIAN DAN PEMBAHASAN}

\section{Kondisi Awal Pembelajaran dalam Penerapan Kurikulum 2013}

Data variabel implementasi pembelajaran dengan tuntutan kurikulum 2013diperoleh menggunakan angket tertutup dengan jumlah butir 48. Skor minimal per butir 1 dan skor maksimal per butir 4 (empat alternatif jawaban). Dengan demikian rentang skor yang ditetapkan untuk variabel kesesuaian implementasi pembelajaran dengan tuntutan kurikulum 2013 adalah dari 48 sampai dengan 192, rerata kriteria (Mi) sebesar 120 dan simpangan baku kriteria (SDi) sebesar 24. Berdasarkan data hasil penelitian diperoleh rentang skor antara 115 sampai dengan 198, harga rerata (mean) sebesar 152,26, nilai tengah (median) sebesar 149, modus (mode) sebesar 149, dan simpangan baku sebesar 19,639.

Kecenderungan data variabel kesesuaian implementasi pembelajaran dengan tuntutan Kurikulum 2013 dapat diketahui dengan membandingkan besarnya rerata hasil penelitian (empiris) dengan rerata kriteria yang ditetapkan. Dari hasil perhitungan diperoleh rerata data hasil penelitian (empiris) sebesar 150,52. Nilai tersebut lebih besar dibanding rerata kriteria sebesar 19200. Hal tersebut menunjukkan bahwa kesesuaian implementasi pembelajaran dengan tuntutan kurikulum 2013 secara keseluruhan termasuk kategori di atas rerata. Selanjutnya kecenderungan dari masing-masing skor tersebut dapat dibedakan menjadi lima kategori yang memiliki rentang antara 48 sampai 192. Gambaran secara rinci dapat disajikan pada Tabel 2.

Berdasarkan persentase kecenderungan data variabel tersebut dapat diketahui bahwa kesesuaian implementasi pembelajaran dengan tuntutan kurikulum 2013 secara umum cenderung termasuk dalam kategori tinggi sampai sangat tinggi. Hal ini selaras dengan rerata hasil penelitian yang telah dianalisis.

Berdasarkan analisis deskriptif dapat pula diketahui pencapaian skor variabel kesesuaian implementasi pembelajaran dengan tuntutan kurikulum 2013 dengan cara membandingkan skor total yang dicapai (empiris) dengan skor total tertinggi yang ditetapkan. Untuk variabel kesesuaian implementasi pembelajaran dengan tuntutan kurikulum 2013 diperoleh skor total 15052 dan skor tertinggi yang ditetapkan adalah 19200 sehingga skor variabel kesesuaian implementasi pembelajaran dengan tuntutan kurikulum 2013 mencapai $78,40 \%$ dari skor tertinggi yang ditetapkan dengan kategori tinggi.

Tabel 2. Persentase Kecenderungan Skor Variabel Kesesuaian Implementasi Pembelajaran dengan Tuntutan Kurikulum 2013

\begin{tabular}{ccccc}
\hline No & Interval & Kategori & Jumlah & Persentase (\%) \\
\hline 1 & $154,6-192$ & Sangat Tinggi & 30 & 30 \\
2 & $135,4-153,6$ & Tinggi & 61 & 61 \\
3 & $105,6-134,4$ & Sedang & 9 & 9 \\
4 & $86,4-104,6$ & Rendah & - & - \\
5 & $48-85,4$ & Sangat Rendah & - & - \\
& Jumlah & & 100 & 100 \\
\hline
\end{tabular}


Tabel 3. Kesesuaian Implementasi Pembelajaran dengan Tuntutan Kurikulum 2013 Aspek Pendahuluan

\begin{tabular}{llcc}
\hline No & \multicolumn{1}{c}{ Pernyataan } & Rerata & $\begin{array}{c}\text { Pencapaian } \\
\text { Skor (\%) }\end{array}$ \\
\hline 1 & Menyampaikan manfaat materi pembelajaran & 3,32 & 83 \\
2 & Menyampaikan kemampuan yang akan dicapai peserta didik & 3,27 & 82 \\
3 & $\begin{array}{l}\text { Menyampaikan rencana kegiatan misalnya, individual, kerja kelompok, } \\
\text { dan melakukan observasi. }\end{array}$ & 3,22 & 81 \\
4 & $\begin{array}{l}\text { Mengaitkan materi pembelajaran sekarang dengan pengalaman peserta } \\
\text { didik atau pembelajaran sebelumnya. }\end{array}$ & 3,22 & 81 \\
5 & Mendemonstrasikan sesuatu yang terkait dengan tema. & 3,19 & 80 \\
6 & Mengajukan pertanyaan menantang. & 3,02 & 76 \\
\hline
\end{tabular}

Tabel 4. Sepuluh Besar Aspek Kesesuaian Implementasi Pembelajaran dengan Skor Tinggi

\begin{tabular}{clcc}
\hline No & \multicolumn{1}{c}{ Pernyataan } & Rerata & $\begin{array}{c}\text { Pencapaian } \\
\text { Skor (\%) }\end{array}$ \\
\hline 1 & Menyesuaikan materi dengan tujuan pembelajaran. & 3,26 & 82 \\
2 & Memancing peserta didik untuk bertanya & 3,26 & 82 \\
3 & Memfasilitasi peserta didik untuk bertanya & 3,26 & 82 \\
4 & Memfasilitasi peserta didik untuk mengamati & 3,26 & 82 \\
5 & Menunjukkan sikap terbuka terhadap respons peserta didik. & 3,26 & 82 \\
6 & Melaksanakan pembelajaran sesuai dengan kompetensi yang akan & 3,23 & 81 \\
& dicapai. & & \\
7 & Menumbuhkan partisipasi aktif peserta didik & 3,23 & 81 \\
8 & Merespon positif partisipasi aktif peserta didik & 3,23 & 81 \\
9 & Menunjukkan hubungan antar pribadi yang kondusif & 3,23 & 81 \\
10 & Menumbuhkan keceriaan atau antusiasme peserta didik dalam belajar & 3,23 & 81 \\
\hline
\end{tabular}

Tabel 5. Sepuluh Besar Aspek Kesesuaian Implementasi Pembelajaran dengan Skor Rendah

\begin{tabular}{llcc}
\hline No & \multicolumn{1}{c}{ Pernyataan } & Rerata & $\begin{array}{c}\text { Pencapaian } \\
\text { Skor (\%) }\end{array}$ \\
\hline 1 & Menerapkan Project based learning & 2,85 & 71 \\
& Memfasilitasi siswa untuk melakukan sintesis & 2,85 & 71 \\
& Menerapkan discovery learning & 2,85 & 71 \\
2 & Memfasilitasi siswa untuk melakukan interpretasi & 2,97 & 74 \\
3 & Menerapkan pendekatan sientific & 2,99 & 75 \\
4 & Memfasilitasi siswa untuk melakukan penilaian & 2,99 & 75 \\
& Memfasilitasi kegiatan yang memuat komponen eksplorasi, elaborasi, & 3,05 & 76 \\
& dan konfirmasi & 3,05 & 76 \\
& Menggunakan proyek/kegiatan sebagai media & 3,05 & 76 \\
& Memberikan masalah untukmemberi kesempatan siswa melakukan & & \\
& proses problem solving & 3,05 & 76 \\
\hline
\end{tabular}


Tabel 6. Kesesuaian Implementasi Pembelajaran dengan Tuntutan Kurikulum 2013 Aspek Penutup

\begin{tabular}{clcc}
\hline No & \multicolumn{1}{c}{ Pernyataan } & Rerata & $\begin{array}{c}\text { Pencapaian } \\
\text { Skor (\%) }\end{array}$ \\
\hline 1 & Memberihan tes lisan atau tulisan . & 3,18 & 80 \\
2 & Mengumpulkan hasil kerja sebagai bahan portofolio. & 3,15 & 79 \\
3 & $\begin{array}{l}\text { Melakukan refleksi atau membuat rangkuman dengan melibatkan } \\
\text { peserta didik. }\end{array}$ & 3,12 & 78 \\
4 & menerapkan penilaian authentic & 3,06 & 77 \\
5 & $\begin{array}{l}\text { Melaksanakan tindak lanjut dengan memberikan arahan kegiatan } \\
\text { berikutnya dan tugas pengayaan. }\end{array}$ & 3,06 & 77 \\
\hline
\end{tabular}

Aspek kesesuaian implementasi pembelajaran secara rinci dalam aspek pendahuluan, kegiatan inti, dan penutup dapat dicermati pada Tabel 3 sampai dengan Tabel 6 .

Berdasarkan data pada Tabel 3 sampai dengan Tabel 6 tampak bahwa implementasi pembelajaran dalam aspek pendahuluan dan penutup pada dasarnya memiliki kesesuaian yang tinggi, sedangkan dalam hal kegiatan inti aspek ketidaksesuaian pada umumnya bersumber dari belum diterapkannya pembelajaran scientific, project based learning, discovery, dan penilaian otentik atau project based learning.

Potensi implementasi Problem Based Learning dalam penerapanKurikulum 2013 di SMK diperoleh melalui angket dengan 14 buah pertanyaan. Hasil lengkap disajikan sebagai berikut. Pertama, pemahaman tentang Problem Based LearningI adalah: (a) 8 orang atau $8 \%$ guru menyatakan sangat memahami PBL; (b) 75 orang atau $75 \%$ guru menyatakan sebagaian besar memahami PBL; (c) 17 orang atau $17 \%$ guru menyatakan kurang memahami PBL.

Kedua, penerapan Problem Based Learning adalah: (a) 4 orang atau $4 \%$ guru menyatakan belum pernah menerapkan PBL; (b) 41 orang atau $41 \%$ guru menyatakan baru pada tahap mencoba PBL; (c) 5 orang atau 5\% guru menyatakan pernah menerapkan PBL satu kali; (d) 34 orang atau 34\% guru menyatakan lebih dari satu kali menerapkan PBL; (e) 16 orang atau $16 \%$ guru menyatakan sudah merasakan manfaat atau dampak penerapan PBL.

Ketiga, pemahaman tentang prinsipprinsip Problem Based Learning adalah: (a) 55 orang atau $55 \%$ guru menyatakan sebagian besar memahami prinsip-prinsip PBL; (b) 45 orang atau $45 \%$ guru menyatakan belum memahami prinsip-prinsip PBL.

Keempat, informasi tentang Problem Based Learning adalah: (a) 8 orang atau $8 \%$ guru menyatakan belum pernah menerima sosialisasi PBL; (b) 84 orang atau $84 \%$ guru menyatakan PBL pernah menerima sosialisasi baik yang diselenggarakan sekolah, maupun pihak luar; (c) 8 orang atau $8 \%$ guru menyatakan mendapat informasi PBL dari sumber pustaka.

Kelima, penyampaian informasi tentang Problem Based Learning dalam pelatihan adalah: (a) 63 orang atau $63 \%$ guru menyatakan bahwa PBL disampaikan dalam pelatihan kurikulum 2013; (b) 37 orang atau 37\% guru menyatakan bahwa PBL disampaikan dalam pelatihan kurikulum 2013;

Keenam, penerapan Problem Based Learning di SMK adalah: (a) 13 orang atau $13 \%$ guru menyatakan baru pada tahap pemahaman implementasi PBL; (b) 44 orang atau $44 \%$ guru menyatakan beberapa guru telah menerapkan; (c) 23 orang atau $23 \%$ guru menyatakan telah menerapkan secara efektif; (d) 20 orang atau $20 \%$ guru menyatakan telah menerapkan PBL secara berkelanjutan.

Ketujuh, kesesuaian dengan pendekatan saintifik adalah: (a) 90 orang atau $90 \%$ guru menyatakan bahwa PBL sesuai dengan pendekatan saintifik dalam penerapan Kurikulum 2013; (b) 10 orang atau 10\% guru menyatakan bahwa PBL kurang atau tidak sesuai dengan pendekatan saintifik dalam penerapan Kurikulum 2013.

Kedelapan, kemungkinan penerapan Problem Based Learning adalah: (a) 94 orang atau $94 \%$ guru menyatakan bahwa PBL sangat 
mungkin diterapkan dalam penerapan Kurikulum 2013; (b) 6 orang atau 6\% guru menyatakan bahwa PBL tidak mungkin diterapkan dalam penerapan Kurikulum 2013.

Kesembilan, mata pelajaran yang sesuai untuk menerapkan Problem Based Learning adalah: (a) 48 orang atau $48 \%$ guru menyatakan bahwa PBL cocok diterapkan di semua mata pelajaran, (b) 51 orang atau $51 \%$ guru menyatakan bahwa PBL cocok diterapkan di mata pelajaran produktif, (c) 5 orang atau 5\% guru menyatakan bahwa PBL cocok diterapak pada mata pelajaran teori.

Kesepuluh, kelayakan penerapan Problem Based Learning adalah: (a) 58 orang atau $58 \%$ guru menyatakan bahwa PBL dapat diterapkan pada semua tingkat; (b) 9 orang atau 9\% guru menyatakan bahwa PBL cocok diterapkan untuk siswa Tingkat I; (c) 27 orang atau $27 \%$ guru menyatakan bahwa PBL cocok diterapkan untuk siswa Tingkat II; (d) 9 orang atau 9\% guru menyatakan bahwa PBL cocok diterapkan untuk siswa Tingkat III.

Kesebelas, program yang dibutuhkan dalam implementasi Problem Based Learning, Sebagian besar guru menyatakan bahwa dalam implemetasi PBL dibutuhkan sosialisasi, penyusunan perangkat, perencanaan pembelajaran, dan evaluasi pembelajaran.

Kedua belas, perangkat yang dibutuhkan dalam implementasi Problem Based Learning, Sebagian besar guru menyatakan bahwa dalam implementasi PBL diperlukan RPP, buku ajar, modul, bahan ajar, media, dan alat evaluasi.

Ketiga belas, kemanfaatan Problem Based Learning adalah: (a) 42 orang atau $42 \%$ guru menyatakan belum merasakan manfaat dari PBL; (b) 58 orang atau 58\% guru menyatakan sudah merasakan manfaat dari PBL.

Berdasarkan data tersebut dapat dicermati bahwa pada dasarnya sekolah maupun guru memiliki potensi yang cukup dalam mengimplementasikan PBL. Semua guru juga menunjukkan persepsi positif tentang $\mathrm{PBL}$ dan menyatakan bahwa PBL memiliki keuntungan dalam meningkatkan kemampuan siswa baik dalam aspek hard skill maupun soft skills.

\section{Kondisi Pembelajaran dalam Penerapan PBL}

Berdasarkan refleksi dari pelaksanaan PBL di sembilan kelompok meliputi SMK bidang teknik mesin, teknik otomotif, dan tata boga, terdapat beberapa hasil implementasi PBL dalam penerapan Kurikulum 2013.

Pertama, menurut para guru, PBL merupakan pembelajaran yang mudah direncanakan. Namun demikian dalam aplikasinya masih dibutuhkan waktu cukup panjang bagi guru untuk memulai merencanakan pembelajaran. Hal ini terutama menyangkut keraguan guru apakah memang PBL bisa diterapkan selaras dengan pembelajaran yang diharapkan dalam penerapan Kurikulum 2013. Masih dibutuhkan waktu bagi tim guru untuk meyakini bahwa PBL memang selaras dengan pembelajaran yang diharapkan di Kurikulum 2013. Dalam implementasi PBL penekanan bahwa PBL adalah pembelajaran yang selaras dengan pendekatan saintifik sangat penting ditegaskan. Hal ini akan mengurangi keraguan guru dalam merencanakan pembelajaran dengan PBL.

Kedua, para guru mengemukakan bahwa PBL akan lebih mudah diterapkan bila didukung dengan materi, media, dan bahan ajar yang lengkap. Dengan materi, media, dan bahan ajar yang lengkap maka guru akan leluasa mendesain permasalahan sesuai dengan karakteristik siswa. Dengan demikian kemampuan guru dalam mengembangkan materi pembelajaran, media, dan bahan ajar merupakan salah satu kunci keberhasilan penerapan PBL.

Ketiga, PBL dapat diterapkan baik pada materi yang sederhana maupun kompleks. Untuk materi yang sederhana PBL dapat diterapkan dengan lebih mudah, namun untuk materi yang sifatnya kompleks beberapa guru yang mencoba masih mengalami kesulitan di tahap-tahap awal. Oleh karenanya guru perlu mencoba penerapan PBL dalam materi pembelajaran yang sederhana terlebih dahulu, setelah memiliki pengalaman dapat menerapkan di materi yang lebih kompleks. Demikian halnya dalam pembelajaran teori, sebagian besar guru menyatakan PBL lebih mudah diterapkan dalam pembelajaran teori meskipun bukan berarti tidak dapat diterapkan di pembelajaran praktek. Untuk pembelajaran praktek, aspek PBL perlu ditekanakan dalam upaya membangun kerangka pikir "bagaimana supaya praktek dapat dilakukan dengan tepat dan efisien”. Sehingga PBL tidak dimaksudkan untuk merubah atau mempertanyakan metode praktek yang sudah baku. 
Keempat, para guru menyatakan bahwa PBL mampu menunjang pembelajaran dalam penerapan Kurikulum 2013. Kemampuankemampuan yang muncul tidak hanya menyangkut penguasaan siswa terhadap materi pembelajaran, namun kemampuan lain yang bersifat afektif atau soft skills dapat berkembang dengan baik. Kemampuan tersebut meliputi kemampuan bertanya, mengemukakan pendapat, kerjasama, disiplin, kerja keras, keaktifan, dan kreatifitas. Dengan demikian jelas bahwa PBL dapat meningkatkan kompetensi siswa secara komprehensif meliputi aspek knowledge, attitude, dan skill.

Kelima, aspek yang paling krusial dan dirasa membutuhkan kerja keras dalam pendekatan saintifik dan PBL adalah mengorganisasi pertanyaan atau menumbuhkan kemampuan siswa untuk menanya. Hal ini dirasakah oleh sebagian besar guru. Dalam aspek yang lain seperti mengumpulkan data, mengasosiasi, dan mengomunikasi siswa relative tidak mengalami kesulitan yang berarti. Oleh karenanya kemampuan menanya bagi siswa merupakan aspek penting yang perlu ditingkatkan.

Keenam, sebagian besar guru menyatakan bahwa kunci keberhasilan guru dalam mengimplementasikan PBL adalah kemampuan untuk mendesain problem atau permasalahan. Makin beragam dan makin kontekstual problem yang didesain makin memudahkan guru dalam mengelola kelas. Iklim kelas akan sangat ditentukan oleh seberapa baik permasalahan dirumuskan.

Berdasarkan catatan-catatan tersebut, maka langkah awal yang perlu dilakukan dalam menerapkan PBL adalah merubah pola pikir pengajar tentang PBL. Perlu diyakinkan bahwa PBL merupakan pembelajaran yang dapat diterapkan dalam mendukung pembelajaran di Kurikulum 2013. Langkah berikutnya adalah perlunya pelatihan guru dalam menerapkan PBL, menyiapkan materi ajar, media, dan bahan ajar. PBL terbukti mampu meningkatkan kompetensi siswa dalam aspek kemampuan (hard skills) maupun sikap (soft skills).

\section{SIMPULAN}

PBL sangat potensial diterapkan dalam penerapan Kurikulum 2013 di SMK. Kesesuaian implementasi pembelajaran dalam penerapan Kurikulum 2013 termasuk kategori Sebagian besar guru menyatakan bahwa PBL layak diterapkan di setiap mata pelajaran dalam implementasi Kurikulum 2013. langkah awal yang perlu dilakukan dalam menerapkan PBL adalah merubah pola pikir pengajar tentang PBL. Perlu diyakinkan bahwa PBL merupakan pembelajaran yang dapat diterapkan dalam mendukung pembelajaran di $\mathrm{Ku}-$ rikulum 2013. Langkah berikutnya adalah perlunya pelatihan guru dalam menerapkan PBL, menyiapkan materi ajar, media, dan bahan ajar

\section{DAFTAR PUSTAKA}

21st Century Student Outcome and Support System. Diambil dari www.21stcenturyskills.org., $\quad$ pada tanggal 23 April 2011.

Anonim. Problem-based Learning, especially in the context of large classes. Website: http://chemeng.mcmaster.ca/pbl/pbl.ht $\underline{\text { m. }}$

Anonim, Problem-Based Learning: An Introduction. Website: www.ntlf.com/html

Anonim, The Advantages of PBL. Website: :http://edweb.sdsu.edu/clrit/learningtree /PBL/PBLadvantages.html.

Demitra (2003). Pembelajaran Pemecahan Masalah Matematika Sekolah Dasar dengan Pendekatan Problem Based Learning. Makalah. Disampaikan dalam Seminar Nasional Teknologi Pembelajaran di Hotel Inna Garuda Tanggal 22-23 Agustus 2003.

Depdiknas. (2003). Undang-Undang Nomor 20 Tahun 2003 tentang Sistem Pendidikan Nasional.

Depdikbud. (2013). Permendikbud No 65 Tahun 2013 Tentang Standar Proses. .

Nurhadi. (2004). Kurikulum 2002: Pertanyaan \& Jawaban. Jakarta: Grasindo.

Sukamto. (2001). Perubahan karalteristik dunia kerja dan revitalisasi pembelajaran dalam kurikulum pendidikan kejuruan. Pidato 
Pengukuhan Guru Besar dalam Pendidikan Kejuruan pada Fakultas Teknik UNY, tanggal 5 Mei 2001.

Tan, Oon-Seng. (2009). Problem-based Learning and Creativity. Singapore: Cengage Learning Asia Pte Ltd.

Wardiman. (2016). Sepanjang Jalan Kenangan, Bekerja dengan Tiga Tokoh
Besar Bangsa. Jakarta: Kepustakaan Populer Gramedia.

Wagiran. (2010a). Pengembangan Pembelajaran Model Problem Based Learning dengan Media Pembelajaran Berbantuan Komputer dalam Matadiklat Measuring bagi Siswa SMK (Tahun Kedua). Yogyakarta: Lembaga Penelitian UNY. 